\title{
Customer Psychological Empowerment as a Critical Source of Customer Engagement
}

\author{
Caroline Morrongiello, ${ }^{1}$ Gilles N'Goala, ${ }^{2}$ and Dominique Kreziak $^{3}$ \\ ${ }^{1}$ IREGE Research Center, IAE Savoie Mont-Blanc-University Savoie Mont-Blanc, \\ Annecy-le-Vieux, France \\ ${ }^{2}$ MRM Research Center, University of Montpellier, Montpellier, France \\ ${ }^{3}$ IREGE Research Center, IAE Savoie Mont-Blanc-University Savoie Mont-Blanc, \\ Chambéry, France
}

\begin{abstract}
Interpersonal influence today includes an extension in cyberspace in the form of e-wordof-mouth (eWOM), thereby transforming customers into information producers. Companies nonetheless continue to experience difficulty in encouraging customers to engage online respecting company brands or to participate in co-creating value and promoting company products via the Web. This research examines how customer psychological empowerment, namely the extent to which customers feel that they exert power in the marketplace, potentially enhances brand engagement. Using structural equation modeling, each of a qualitative and quantitative study has been conducted at a French ski resort $(N=753)$. Findings demonstrate that customers engage for three reasons: belief that they can help companies without resorting to the venting of negative feelings (punishment), brand attachment, and reciprocity based on the perceived sincerity of online comments penned by other customers.
\end{abstract}

Keywords: Customer psychological empowerment; customer engagement; e-reputation; online platform; tourism

"We [live] in the age of the empowered customer." This claim by Bernoff and Schadler (2010, Forrester Research) has become a credo for many managers. Indeed there would appear to be a broad consensus among practitioners and academics alike that stakeholders in today's connected world-customers among them-have become empowered. As a result, relationships between customers and commercial enterprises tend to be increasingly more balanced. In the 21 st century, stakeholders have the power to compare and select the best available offers in a mere click, to post comments on various websites, and to interact with one another on social media. They exercise power over brands and companies, rewarding the best and punishing the worst. They

Address correspondence to Caroline Morrongiello, Lecturer in Marketing, IREGE Research Center, IAE Savoie Mont-Blanc-University Savoie Mont-Blanc, Annecy-le-Vieux 74944, France. E-mail: caroline.morrongiello@ univ-smb.fr 
collectively cooperate with other customers and opinion leaders to restore equity and justice in the marketplace, contribute to online platforms and communities, and assist one another.

The tourism industry has been particularly impacted by developments in this area. Destinations and hospitality entities, such as hotels and restaurants, despite not exercising total control over communications, find themselves faced with three new phenomena: (1) the omnipresence of specialty community sites, TripAdvisor in particular; (2) the growing influence of online travel agencies which currently account for nearly three quarters of all comments published; and (3) the emergence of new "voices" by dint of travel blogs, traveler forums, and social networks. The hospitality industry provides an example of a sector with respect to which a sound e-reputation is not only strategically important, but also a prerequisite for survival. Stakeholders thus become brand carriers capable of altering how a company is perceived, shaping a company's e-reputation and ultimately impacting commercial success (Chun and Davies 2001). Companies, like destinations, seek to attract and manage engaged customers who exhibit "a vast array of behaviors, beyond purchases, including word-of-mouth (WOM) activity, recommendations, helping other customers, blogging [and] writing reviews" (Van Doorn et al. 2010, 253).

The development of opinion platforms in tourism and other sectors of industry bring to the fore issues relating to engagement (how to engage the majority of stakeholders, especially customers) and empowerment (how to redistribute power and control over communications in the marketplace). These issues of engagement and empowerment do not relate solely to customers, customer roles, and customer activities in the market. Many other stakeholders, including opinion leaders, service providers, retailers, and employees, similarly impact companies and brands. Owing to sheer numbers, customers across sectors of industry, tourism in particular, are readily regarded as critical stakeholders whose product appreciations are credible.

Customer engagement has become a leading priority, prompting managers to develop strategies, tools, and incentive measures designed to lend a voice to their customers. That said that the vast majority of customers are simply online opinion seekers since precious few take the time to create content or contribute to online conversations (Moe and Trusov 2011; Minazzi 2015). Most indeed remain passive, qualifying as "lurkers." What is published online about brands and e-reputations, therefore, depends heavily on a few key opinion leaders and a small number of customers whose views do not necessarily mirror those of the majority of customers. Through inattentiveness to the need for frequent customer motivation and encouragement and abiding obligation to spur customers to take concrete brand-related action, companies fail to tap into and exploit customer promotional capacity. The situation begs the following questions: Why do online customers choose to remain passive? How can managers help customers overcome their inhibitions? Do customers remain passive because they feel powerless in the market? Do customers take a more active stance when they believe they can change things, influence others, and/or bring about change in the market together with others? The development of opinion platforms also raises issues about respecting customer and company power sharing, as well as distribution in the marketplace (Wathieu et al. 2002; Wright, Newman, and Dennis 2006; Lawer and Knox 2008). In online environments, communications tend to be more "horizontal" (conversation with all customers) than "vertical" (message from companies to target customers). Regardless, many e-reputation managers remain reluctant to revise the manner in which they operate. If, on the one hand, they seek out engaged customers ready and willing to express themselves online, write product reviews, share their experiences, and generate Web-based content (Van Doorn et al. 2010), on the other hand they do not really trust their customers and fear 
the potentially damaging impact of negative WOM. Community or e-reputation managers, therefore, retain a high level of control over what customers say online by answering customers directly, moderating as required, deleting customer comments, managing e-reputations, engaging in court challenges, and so on. Our view in this regard is that enhanced company control and enhanced customer engagement are irreconcilable. Companies must first accept to share power and control over communications with customers if they are to be successful in securing enhanced customer engagement.

In topical literature, issues of customer engagement and empowerment are addressed separately despite customer empowerment appearing to be a prerequisite for customer engagement. Prior research has investigated many motivational drivers that enhance or inhibit WOM in online and offline environments (Sundaram, Mitra, and Webster 1998; Hennig-Thurau et al. 2004; Hennig-Thurau, Henning, and Sattler 2007; Thompson and Sinha 2008; Trusov, Bucklin, and Pauwels 2009). To our knowledge, however, no research conducted to date clearly addresses the issue in terms of power sharing and distribution. It is important to understand how one can develop customer psychological empowerment given the latter's potential to facilitate customer engagement in online environments.

The objective of this article is twofold. Firstly, we seek to examine the theoretical foundations of customer empowerment. Drawing inspiration from the definition proffered by Spreitzer (1995), we define customer psychological empowerment as an intrinsic motivation based on cognitions about oneself as the latter relate to one's role in the market. Building on this definition, we endeavor to first develop a unifying conceptual framework that underscores customer ability to impact e-reputations based on psychological empowerment. Secondly, we seek to develop and empirically test a model that correlates customer psychological empowerment to online engagement.

We begin with a review of customer empowerment literature followed by the development of a theoretical framework designed to correlate customer psychological empowerment with customer engagement behavior in an online environment. Model development derives from an extensive review of customer empowerment, customer engagement, and WOM literature, as well as a preliminary qualitative study carried out in the tourism industry. We then test our model by means of a quantitative study conducted with tourists at Grand Bornand, which is a French ski resort. Lastly, we draw conclusions from our studies and discuss theoretical and managerial implications. In particular, we examine how company empowerment strategies can lead to customer psychological empowerment and engagement behavior. The research technique we apply to customers may, of course, extend to other stakeholders such as service providers, retailers, and others. In electing to focus on customers, our intention is to illustrate that the latter can be deemed to represent all manner of other online audiences. In matters relating to e-reputations, marketing activities can help us better grasp issues relating to organizational studies by shedding light on the consumer behavior exhibited by specific stakeholders.

\section{CONCEPTUALIZING CUSTOMER EMPOWERMENT IN THE MARKETPLACE}

From an extensive, cross-discipline literature review (human resource management, marketing, and organizational behavior), we develop an integrative conceptual framework to bring to the fore power sources (French and Raven 1959) and power capacities (Rowlands 1995), the aim being to distinguish psychological empowerment (perceived power) from structural empowerment (given 
power), and to address the issue of the empowered customer from an e-reputation perspective (Thomas and Velthouse 1990; Spreitzer 1995; Konczak, Stelly, and Trusty 2000; Matthews, Diaz, and Cole 2002; Tuuli and Rowlinson 2007; Cho and Faerman 2010).

\section{POWER SOURCES AND POWER CAPACITIES APPROACH}

The notion of empowerment can take on a number of different meanings depending on the intentions expressed or implied by users. To understand how people perceive power and the origins of power, we refer to literature on power sources (French and Raven 1959). Inspired by Weber (1947), French and Raven (1959) distinguish different types of influence based on different relational bases. They define power as the ability to determine, influence, or direct the conduct of those with whom one entertains a relationship. Hence we have the following classification, which comprises five different power bases and three different power sources:

(1) Expert power, or the "power to" do something, thus a source of expertise-related power; (2 and 3) Reward and coercive power, which refer to the "power on" or "power over" someone to reward or punish him or her, thus a source of power relating to reward or punishment; and (4 and 5) Legitimate and referent power, which refer to "power with" or source of power relating to the ability to influence others and the resulting impact on others.

Following in the wake of French and Raven (1959), Rowlands (1995) focuses on the specific notion of empowerment and uses it in the context of development interventions with women. The author's analysis reveals that empowerment is not a fixed entity, but rather depends on the context and specifics of each individual woman's situation or that of a group of women. When empowerment is defined in greater detail and includes the constituents of power and the uniqueness of the process, the concept becomes even more useful for analytical and planning purposes.

Personal capacities are defined as the empowerment reflects the development of selfconfidence, self-esteem, and the sense of agency. These capacities lead individuals to ponder whether they have sufficient expertise and self-confidence. We associate these personal capacities with the "power to" source proffered by French and Raven (1959). Relational capacities are defined as the empowerment can influence the nature of a relationship and decisions made within this relationship as relate to the development of strategic know-how in human relations. Individuals are about to learn how to influence the outcome of an exchange. We postulate that these relational capacities correspond to the "power on" or "power over" source advanced by French and Raven (1959). Collective capacities are defined as works by individuals considered collectively exert a greater impact than they would on their own. Hence the group is deemed to achieve a degree of collective consciousness. In so doing, the group is able to express and defend common interests, and develop both a group identity and sense of collective agency. We relate these collective capacities more closely to the "power with" source tendered by French and Raven (1959).

Based on our analyses, we propose an adaptation of the concept of power with five power sources (French and Raven 1959) and three power capacities (Rowlands 1995). These capacities demonstrate that there are three ways in which to exercise power for each power source. The approaches are then adapted for the purposes of this study, namely, assessing customer 


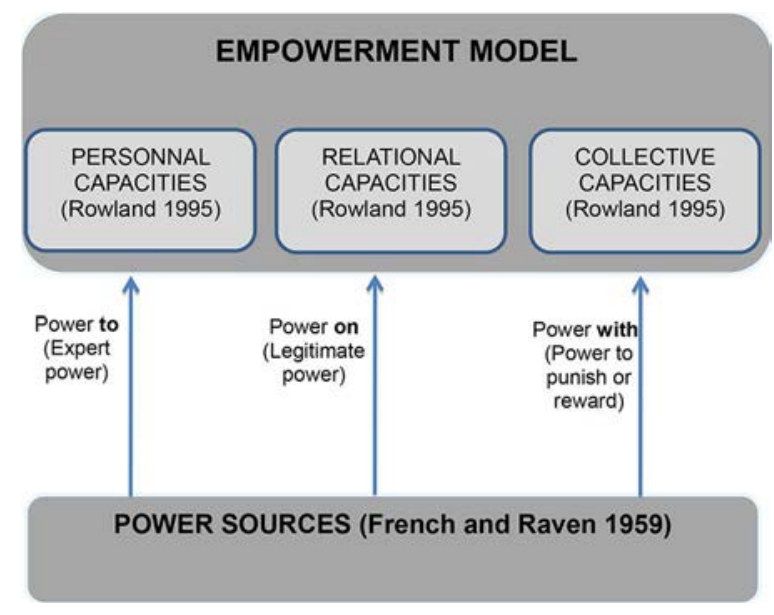

FIGURE 1 Link between empowerment and power sources.

empowerment in the marketplace, by putting personal, relational, and collective power capacities into perspective based on the various power sources.

Hence, we combine the Rowlands (1995) and French and Raven (1959) approaches to assess each of the three dimensions in depth. The proposed model is presented in Figure 1.

These capacities demonstrate that there are three ways in which to exercise power, while the power sources indicate whence the perceived capacities originate. The power sources are not the same and depend on whether one chooses to focus on personal capacities (expert power), relational capacities (legitimate power), or collective capacities (power to reward or punish). We do not, however, explicitly distinguish between perceived power and given power, and hence the necessity for a complementary framework.

\section{PSYCHOLOGICAL AND STRUCTURAL EMPOWERMENT PERSPECTIVES}

Spreitzer (1997) defined two general perspectives of empowerment in a business context, namely, psychological and relational. Psychological empowerment refers to the power perceived by the individual, while structural empowerment refers to the power given by the organization. Although these concepts have been studied in marketing literature (Wathieu et al. 2002; Harrison, Waite, and Hunter 2006), the distinction between the two needs clarifying. In human resource management literature, psychological empowerment refers to employee perception of empowerment (Thomas and Velthouse 1990; Spreitzer 1995, 1997; Matthews, Diaz, and Cole 2002; Tuuli and Rowlinson 2007). In contrast, topical literature refers to empowerment as a top-down process (Conger and Kanungo 1988), which is said to occur when the higher levels within a hierarchy share power with the lower levels (Spreitzer 1997; Konczak, Stelly, and Trusty 2000; Matthews, Diaz, and Cole 2002; Tuuli and Rowlinson 2007). We surmise that power sources and capacities can apply to either psychological or structural empowerment. Both can be analyzed by means of personal capacities via the "power to" source, relational capacities via the "power on" source, and collective capacities via the "power with" source. 


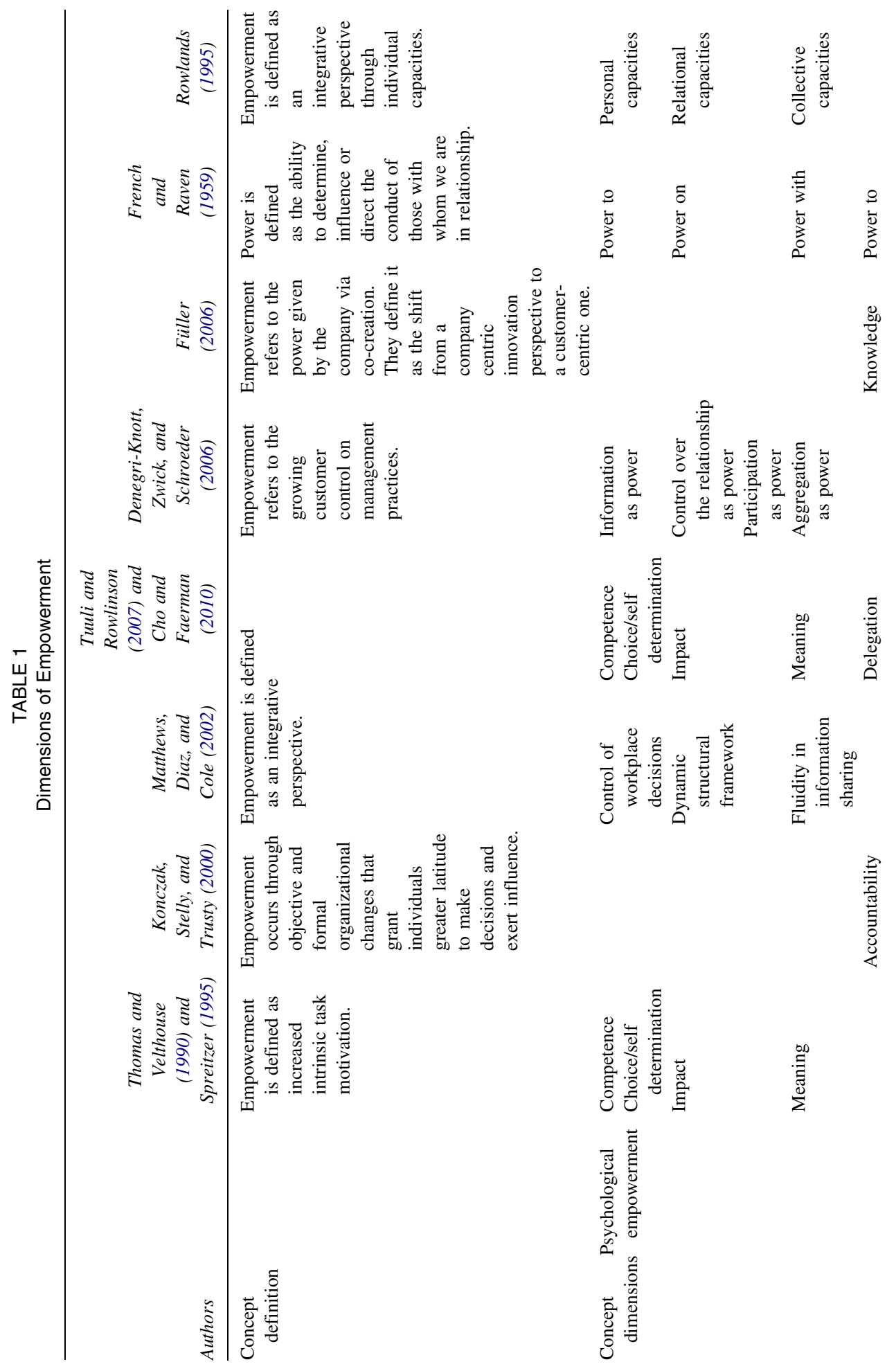




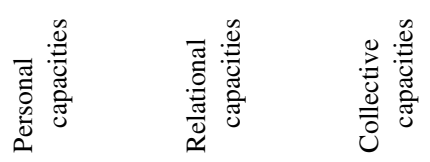

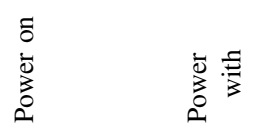

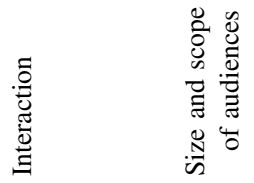

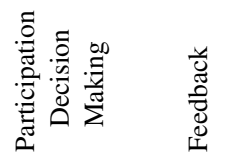

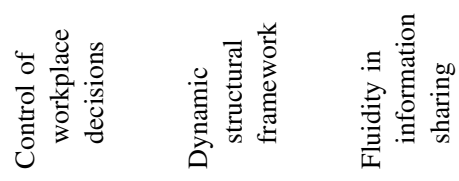

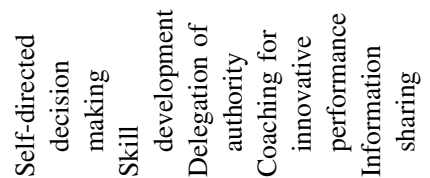

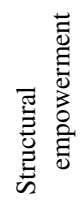


Research points to different dimensions of psychological empowerment (competence, choice, impact, control, and meaning), which are also consistent with our three-dimensional model (Thomas and Velthouse 1990; Spreitzer 1995; Cho and Faerman 2010; Tuuli and Rowlinson 2007). The "competence" and "choice" dimensions refer to personal capacities: "competence" as an individual's belief in his or her capacity to perform activities with skill; and "choice" as self-determination together with competence. This facet of power relates closely to the ego concept and depends on how customers view themselves in relation to a product (competence or expertise) or a brand (attachment, self-expression). An individual's attachment represents "the strength of the bond connecting the brand/company with the self" (Park et al. 2010). In instances of the like, the customer seeks out both ego reinforcement and ego defense, and expresses his or her identity, ego, and values through the brands that he or she consumes (Fournier 1998; Escalas and Bettman 2003). This attachment lends the individual the strength to express his or her feelings and opinions to others, hence "power to."

Another empowerment dimension, developed by Matthews, Diaz, and Cole (2002), also corresponds to these personal capacities, namely "control over workplace decisions" or power over one's professional endeavors. Additional dimensions pertaining to relational capacities include "impact," which refers to the degree to which an individual exercises influence over his or her work environment, and "dynamic structural framework," developed by Matthews, Diaz, and Cole (2002), whereby a company provides a clear set of modifiable guidelines to assist in employee decision-making, hence "power on." The collective capacities can be seen in the "meaning" dimension or value of a work goal or purpose assessed in relation to an individual's own ideals and standards, given that "meaning" represents the general sense. "Fluidity in information sharing," developed by Matthews, Diaz, and Cole (2002), also corresponds to this general sense and the collective capacities: the information is shared and accessible to all internal stakeholders, hence "power with."

Viewed from a different perspective, research on structural empowerment can be deemed to refer to personal, relational, or collective capacities that are not perceived but given, allowed, or managed by the organization. Some research focuses on "accountability," "self-directed decision-making," "skills development" (Konczak, Stelly, and Trusty 2000), and "delegation" (Tuuli and Rowlinson 2007; Cho and Faerman 2010), which relate to the development of personal capacities. Relational capacities can be seen in the structural empowerment dimensions of "delegation of authority," "coaching for innovative performance" (Konczak, Stelly, and Trusty 2000), and "participatory decision-making" (Tuuli and Rowlinson 2007; Cho and Faerman 2010), which enable employees to exercise influence over decisions taken, hence "power on." Lastly, "information sharing" (Konczak, Stelly, and Trusty 2000) and "feedback" (Tuuli and Rowlinson 2007; Cho and Faerman 2010) relate to collective capacities, the sharing of experience, and performance, hence "power with." Table 1 shows how the various dimensions of psychological and structural empowerment can be classified by power source and capacity.

\section{CHALLENGES ASSOCIATED WITH EMPOWERED CUSTOMERS}

While research into empowerment has tended to focus primarily on human resource management and organizational science, the trend would appear to be towards increasing adaptation 
for marketing purposes, implying that customers have been given (structural empowerment) or at long last perceive (psychological empowerment) new roles in the marketplace (Denegri-Knott, Zwick, and Schroeder 2006). For instance, customers can use--or abuse-their power by implementing various online strategies designed to maximize benefits gained at the expense of and resulting in a potential loss of power for companies.

Denegri-Knott, Zwick, and Schroeder (2006) identify customer strategies that clearly relate to customer empowerment: (1) information and participation as power, where customers use information as a means of improving their decision-making skills; (2) control over the relationship and participation as power; from the customer/company relationship, co-creation occurs as a result of participation in the creation of content; and (3) aggregation as power when customers interact with other people.

Research into empowerment in marketing nonetheless remains essentially conceptual and focuses on processes instituted by companies to enhance customer participation, coproduction, co-innovation, and co-creation, thereby, detailing how customers are empowered, the manner in which they participate, and perform various tasks, and how they help companies produce, improve, and promote products and services (Johnson and Rapp 2010). Literature on innovation explains how customers are able to participate in brand conversations worldwide and influence product innovations through carefully managed active dialogue (Füller et al. 2010; Fuchs and Schreier 2011). Füller (2006) view empowerment as a shift from company-centric to customer-centric innovation, and point up the following three key dimensions: knowledge to develop appropriate products; interaction to secure invaluable customer input; and audience size and scope necessary to achieve interaction with potential customers.

In service marketing literature (Mills and Morris 1986), customers are viewed as 'part-time' employees (Mills and Morris 1986) whom companies can empower-almost as traditional employees - to enhance productivity and efficacy (task delegation, information sharing, and coaching). While some tasks are outsourced to customers, customer empowerment is not a given. Customers may still feel powerless in the face of large companies. In the following discussion, we focus on perceived power (psychological empowerment) rather than on the power that organizations "lend" to customers (structural empowerment). Basing ourselves on the definition advanced by Spreitzer (1995), we define customer psychological empowerment as an intrinsic motivation based on cognitions about oneself as the latter relate to one's role in the market. Hence, we opine that when customers believe in their personal ("power to"), relational ("power on"), and/or collective ("power with") capacities, they can expect to exercise relative power in the marketplace.

In this article, we focus on customer ability and willingness to spread WOM, make recommendations, help other customers, and write reviews or a blog (Van Doorn et al. 2010). Thanks to the Internet and the development of opinion platforms and social networks, customers can readily seek out and broadcast information relating to products, services, brands, retailers, and destinations (Harrison, Waite, and Hunter 2006). In cyberspace, every customer can connect to a global community of users, employ a variety of media to spread WOM messages, convey experiences anonymously, and enduringly converse with others, such as companies and customers, online. Customer power and roles in the marketplace are evolving rapidly. Customer voices increasingly matter, and companies must carefully manage customers to build and protect corporate e-reputations. 


\section{UNDERSTANDING CUSTOMER ENGAGEMENT}

A theoretical model of customer engagement has been developed based on topical literature and supported by a qualitative study. The various elements of the model are described in what follows.

\section{Critical Role of Customers Respecting E-Reputations}

The study of e-reputations is relatively new, and related terminology continues to evolve. E-reputation refers to a company's standing plotted on the continuum of time and defined as perceptions and beliefs about the company based on previous interaction (Campbell 1999; Prabhu and Stewart 2001). It is a collective construct entailing all stakeholder views of the company. Accordingly, reputations subsume images held by external stakeholders, customers in particular (Chun and Davies 2001). Reputations build on signals from a company, stakeholder/company relationship experiences, and interactions among stakeholders. This last point is critical for e-reputations derived specifically from electronic contacts. Reputations and e-reputations differ from the standpoint of Web 2.0 "sociability" (Castellano and Dutot 2013). The advent of Web 2.0 has impacted the proliferation of information sources and resulted in ever increasing volumes of information being transmitted (Paquerot et al. 2011). Web 2.0 is supported by the concepts of sharing and social presence which empower customers and provide them with the opportunity to impact images and e-reputations.

Empowered customers become brand carriers, capable of altering how a company is perceived. These customers will ensure the success or failure of a company from the dual standpoint of reputation and e-reputation (Chun and Davies 2001). E-reputation management strategy entails the following four key elements (Castellano and Dutot 2013): (1) online brand management by defining a company's virtual identity; (2) reliability of online information which can impact how a company is perceived by customers; (3) presence on social media to monitor what customers are saying; and (4) transparency given that the company must address the concerns of truthfulness to sustain consumer confidence. These essential elements of online reputation management strategy relate to one stakeholder in particular: the customer. Content created and disseminated on online platforms can influence customer perceptions and prompt interaction and engagement with the company (Murdough 2009). Customer engagement can therefore be deemed a critical antecedent of e-reputation.

\section{FROM CUSTOMER EMPOWERMENT TO CUSTOMER ENGAGEMENT}

Van Doorn et al. (2010, 253) describe customer engagement as "the customer's behavioral manifestation towards a brand or firm, beyond purchase, resulting from motivational drivers. Customer engagement behaviors (CEBs) include a vast array of behaviors including word-ofmouth (WOM) activity, recommendations, helping other customers, blogging, writing reviews, and even engaging in legal action." They go on to develop a unifying conceptual framework designed to encompass a breadth of customer behaviors extending to the likes of patronage, co-creation activity, and WOM, all previously examined on a piecemeal basis. Jahn and Kunz 
(2012) concur, pointing to the importance and necessity of action to engage online customers. Customer engagement is founded on five specific subprocesses: "learning," "sharing," "advocating," "socializing." and "co-developing" (Brodie et al. 2011). Customer engagement can be positive, neutral, or negative. Web 2.0 can therefore prove both an opportunity for and a threat to organizations. Communications originating from online platforms have more pronounced, long-term effects than company-initiated communications (Hennig-Thurau, Henning, and Sattler 2007; Thompson and Sinha 2008; Trusov, Bucklin, and Pauwels 2009).

Online reviews and their dispersion across heterogeneous customer groups are predictive of new product successes and failures (Godes and Mayzlin 2004; Chevalier and Mayzlin 2006). Content is a significant indicator of customer brand knowledge and perceptions which help marketing managers predict product sales (Liu 2006), understand company valuation (Tirunillai and Tellis 2012), and infer competitive market structure (Netzer et al. 2012).

However, engaging customers is no easy task. Customers may readily seek out the opinions of others before making a purchase but are far less likely to share their opinions online (Moe and Trusov 2011). That said, the object of Web 2.0 is not simply to identify a relatively small number of influential, knowledgeable, innovative, and communicative opinion leaders who exercise influence over a large number of followers. It is the role of managers to secure and inspire pools of customers eager to share advice and experiences with other members of the same global community. The challenge lies in determining how best to engage a plurality of customers.

Previous eWOM studies indicate that consumers generally express their opinions for the following reasons: (1) to reinforce their ego (expertise, self-expression); (2) to help other consumers (altruism) without expecting any rewards in return; (3) to exert power, impact company decisions, and restore equity in consumer/company relationships; (4) to vent negative feelings (vengeance) and thereby ascribe rewards and punishments; and (5) to help companies improve services and boost business (Sundaram, Mitra, and Webster 1998; Hennig-Thurau et al. 2004; Hennig-Thurau, Henning, and Sattler 2007; Thompson and Sinha 2008; Trusov, Bucklin, and Pauwels 2009). Through these motivational drivers, we can appreciate that customers do recognize, at least to a certain degree, their potential power, control, and influence in the marketplace. The exercise of power is neither coercive nor negative by nature. Customers may believe that they are part of a global community and positively impact the market (assist the company and other consumers, and help regulate the market). Customers indeed act as market regulators and feel a certain responsibility to broadcast trustworthy comments and ratings based on individual experiences designed to help the community at large. Many customers are knowledgeable of their newfound personal, relational and collective capacities, as well as the roles they play in the market.

\section{CUSTOMER EMPOWERMENT AS A SOURCE OF ONLINE CUSTOMER ENGAGEMENT}

Based on prior literature and the above preliminary qualitative study, we have devised a conceptual framework to explain online customer engagement. According to the three-dimensional conceptualization of customer empowerment, we have built a theoretical model that features the three types of power exercised: "power to," "power on," and "power with." 


\section{EXPLORING CUSTOMER PSYCHOLOGICAL EMPOWERMENT AND CUSTOMER ENGAGEMENT IN THE TOURISM INDUSTRY}

We conducted a qualitative study to explore psychological empowerment and customer engagement in the tourism sector. Online reviews have become an essential source of information for potential customers when planning a trip (Pan and Fesenmaier 2006; Xiang and Fesenmaier 2006; Xiang and Gretzel 2010). However, only a minority of travelers engage and post comments, ratings, and online reviews pertaining to destinations, hotels, and restaurants (Yoo and Gretzel 2012).

To investigate customer psychological empowerment, we first carry out a qualitative study (15 semidirected individual interviews) to better understand how online customers engage their power capacities. Why do individuals seek out and share personal opinions on the Internet? How do they proceed? Are they aware of the power that they wield in so doing? What is the extent of their confidence in online comments? The study was carried out at Grand Bornand, a ski resort in France's northern Alps. Each interview lasted 45 minutes on average. The first segment of the interview guide developed dealt with visitor onsite experience at the resort. Respondents were then placed in front of a computer and asked to post a comment about their trip. They were subsequently requested to consult commentary on the Web and provide feedback. By proceeding in this manner, we were able to position them as opinion platform users and bring to the fore a number of themes that regularly recur with Internet users. To analyze content, we grouped together respondent observations by theme (Tesch 1990; Savoie-Zajc 2000). We then coded observation operations. Employing an abductive approach, the data were analyzed and categories of meaning were allowed to emerge from respondent remarks. These categories were subsequently compared with existing empowerment frameworks, the object being to ascertain potential relationships between emerging categories and dimensions of power sources or capacities.

While processing the qualitative data on why customers engaged in online platforms in this particular context, inter-judge agreement was achieved respecting eight categories of meaning (Robert and Bouillaguet 1997). The latter were, in turn, grouped together based on primary target, namely, the individual at the center of the matter. Some categories centered on the individual and were labeled "Self" target. Others focused on the company about which they intended to post a comment and were labeled "Other" target. Other categories yet related to companies or customers in general and were labeled as "Others" target. The target makes it easier to understand for whom, on whom, and with whom the customer seeks empowerment.

The eight initial categories are presented and grouped together under these three labels.

\section{"SELF" TARGET AND CUSTOMER PERSONAL CAPACITY}

\section{Self-Confidence}

Some people felt that they were sufficiently informed, poised to organize their trip, and able to provide sound advice. "I think my review may have an impact, because I know that what I have written is true!" (Louise-Marise, age 68). Self-confident customers are less reluctant to share their opinions since they believe that they have expertise in a field which could be useful to others. 


\section{Ego-Reinforcement}

Respondents often demonstrated attachment to the resort and local professionals, and sought to contribute to development. Some "worked" for the resort and regularly intervened to defend the resort as "loyal customers." "I can help promote the area and encourage more tourists come here" (Brigitte, age 44). Since the brand represented who they were (identity basis), or was personally relevant (instrumentality basis), customers were more likely to actively promote resort products and services online and to become online resort "advocates." The relation to the self-concept engenders the link to the ski resort.

We surmise that the "Self" target relates to perceived "power to."

\section{"OTHER" TARGET AND CUSTOMER RELATIONAL CAPACITY}

\section{Helping the Company}

Participants who engage on opinion platforms often do so to help companies improve services. "Comments and suggestions can help hotels make improvements" (Fabienne, age 40).

\section{Vengeance}

Participants use electronic platforms as a means of punishing companies. Emilie (age 25) states: "When I'm very negative in my answers, it is a way of 'punishing' them for not meeting my expectations." Users like this appear as avengers and do not hesitate to use the power they enjoy via Web 2.0. We surmise that the "other target" relates to perceived "power on" or "power over" the company.

\section{“OTHERS” TARGET AND CUSTOMER COLLECTIVE CAPACITY}

\section{Collective Consciousness}

Respondents view opinion platforms as an opportunity to exercise their freedom of expression and to wield power by adding their voice to that of others: "I feel that all these consumer voices combined are extremely important, more important and more objective than those of the company" (Didier, age 49). People seek meaning in what they have to say by taking action and engaging online.

\section{Altruism towards Other Customers}

Some are really altruistic towards those who do not know the resort. "For people who do not know the resort, I think it can help them to make the right choice" (Nathalie, age 38). 


\section{Other Customer Honesty}

Respondents demonstrate skepticism about other customers' honesty: 'I'm suspicious whether comments are positive or negative. I need to have a look for myself because I do not trust people and what they have to say. Some people might not like the staff or the hotel and can say whatever they want" (Nathalie, age 46); "I think that there are some very nasty people who, because they are unhappy, sometimes go a step too far" (Josiane, age 61). When customers believe in the sincerity of other customers' comments, they are more likely to share and express their opinions with them out of reciprocity. This is consistent with previous studies (Sher and Lee 2009), underscores that online reviews foster customer skepticism, and casts doubt on the trustworthiness of online comments.

\section{Company Honesty in General}

The qualitative study highlights the fear of being manipulated by companies suspected of posting false comments: "I want to run away! This is wrong! It looks like it has been forged! It's too positive! It's like everything is perfect! Everyone is beautiful, everyone is nice! I don't buy it for a second!!!!!!! It's all manipulation ... meaningless drivel!" (Monique, age 70). "If the commentary is too positive, one must be careful, it could be the boss writing" (Didier, age 49). "I don't know whether the company suppresses negative comments when they get them" (Fatima, age 48). One seemingly forged comment can shed doubt on all the other comments appearing on a site, in the same manner as the total absence of negative comments. Internet users do read available comments, but remain suspicious about brand practices on opinion platforms. We, therefore, found honesty to be critical in matters of social exchange. Brand confidence and brand credibility prompted consumers to participate (Frisou 2000), and possibly reflected a societal desire for market regulation through collective action, as Nathalie (age 38) explains: "We need comprehensive quality control over comments posted to know what is true."

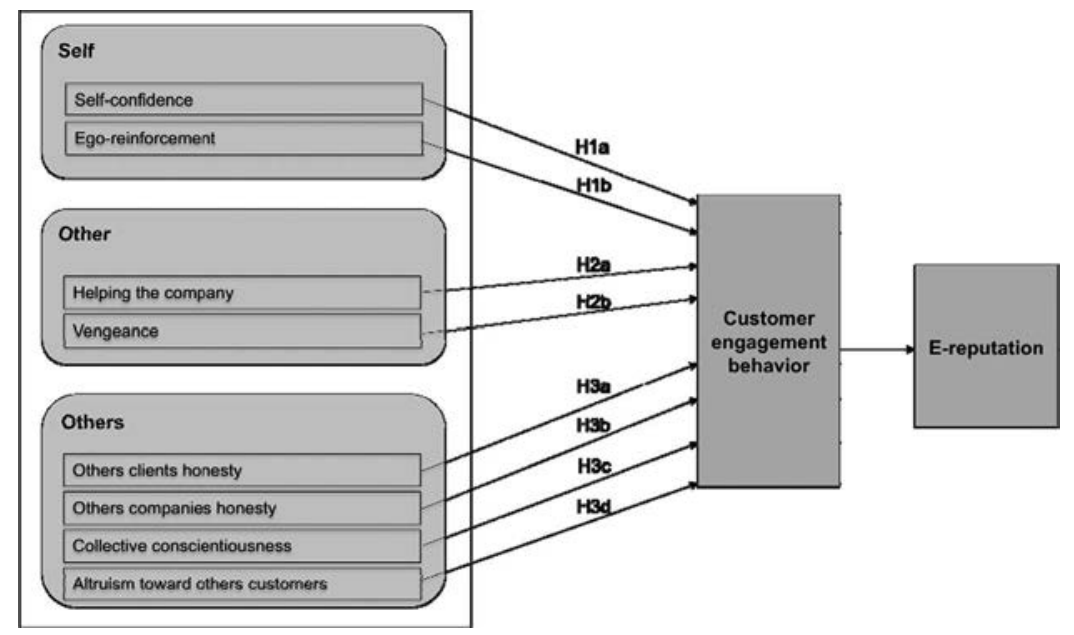

FIGURE 2 The conceptual model. 
These categories and the "others" target relate to perceived "power with."

Through this qualitative study, we identified targets with respect to which customers engage online and reap the rewards of psychological empowerment through personal, relational and collective capacities. The following hypotheses and conceptual model, presented in Figure 2, have been adapted based on the qualitative interviews conducted.

\section{FORMULATION OF HYPOTHESES}

\section{Hypotheses Relating to the "self" Target}

Previous studies underscore that customers express their opinions for reasons of selfenhancement (Engel, Blackwell, and Miniard 1993; Sundaram, Mitra, and Webster 1998; Hennig-Thurau et al. 2004). Self-confident customers organizing a trip are less reluctant to share their opinions, since they believe they have an expertise in the field. Thus we postulate as follows:

\section{Hla: Highly self-confident customers with competence sufficient to organize a trip engage more} readily than their less-confident counterparts.

As we witnessed in the qualitative study, attached customers are more likely to actively promote online products and services and to become "advocates" on opinion platforms. Park et al. (2010) define "brand attachment as the strength of the bond connecting the brand with the self." It is the relation to the concept of self which engenders the link to the ski resort. The brand being integrated into resort history and identity, we hypothesize as follows:

H1b: Customers seeking ego-reinforcement engage more readily than those who do not.

\section{Hypotheses Relating to the "other" Target}

Customers express their opinions to help the company (Hennig-Thurau et al. 2004), but also to vent negative feelings and ascribe punishment through acts of vengeance (Hennig-Thurau et al. 2004). Thus, we postulate as follows:

H2a: Customers seeking to help a company engage more readily than those who do not.

$H 2 b$ : Customers seeking to vent negative feelings (vengeance) engage more readily than those who do not.

\section{Hypotheses Relating to the "others" Target}

As we observed in the qualitative study, honesty appears to be critical in matters of social exchange. Honesty is defined as reflecting the fact that partners involved in the exchange are sincere, reliable, keeps their word, and fulfill their promises and obligations (Anderson and Narus 1990). We therefore postulate as follows:

H3a: Customers who are confident about other customers' honesty relating to online commentaries engage more readily than those who are skeptical. 
H3b: Customers who are confident about company honesty engage more readily than those who are skeptical.

The qualitative study also points out that people seek out meaning in what they have to say by taking action and collectively engaging online. They aspire to restore equity in the customer/ company relationship, hence the following hypothesis:

H3c: Customers who perceive online platforms as a means of establishing collective consciousness engage more readily than those who do not.

Previous studies (Hennig-Thurau et al. 2004) underline that customers express their opinions to help other customers, hence the following hypothesis:

H3d: Customers who demonstrate altruistic behavior towards other customers engage more readily than those who do not.

\section{TESTING THE MODEL IN THE TOURISM INDUSTRY}

As suggested by Churchill (1979), we employed an iterative process to improve measurement scale reliability and validity. The questionnaire was first administered to a group of students (195) and then to the final sample. Our constructs were subsequently refined to enhance the psychometric qualities of our measurement scales. A quantitative study was conducted, the object being to measure the impact of the previously identified variables on online user engagement.

\section{SURVEY METHODOLOGY}

We forwarded a message via email to individuals appearing on a mailing list provided by Grand Bornand tourist bureau. The Web-based survey was self-administered using Sphinx online software and attracted 753 respondents. To ascertain customer engagement towards Grand Bornand ski resort, we asked respondents to indicate how frequently they had posted online reviews about the ski resort in the last year (on a scale from "1" to " 5 " where "1" = "never" and

\section{TABLE 2}

The Questionnaire

\begin{tabular}{|c|c|}
\hline $\begin{array}{l}\text { First part: "You and } \\
\text { the tourism" }\end{array}$ & $\begin{array}{l}\text { We asked questions about the frequency of holidays, ways of booking, and } \\
\text { behavior in case of satisfaction and dissatisfaction and trip preparation. }\end{array}$ \\
\hline $\begin{array}{l}\text { Second part "You and } \\
\text { the Internet" }\end{array}$ & $\begin{array}{l}\text { We asked questions about Internet and opinion platforms uses. We used our qualitative } \\
\text { results to workout items about exerting power, desire for vengeance, altruism toward } \\
\text { company and toward other customers, skepticism toward professionals' practices, } \\
\text { willingness to help companies (resorts). }\end{array}$ \\
\hline $\begin{array}{l}\text { Third part "You and } \\
\text { Le Grand-Bornand" }\end{array}$ & $\begin{array}{l}\text { We asked questions about frequency, pattern, location, and behavior on the Web regarding Le } \\
\text { Grand-Bornand. We also measure the psychological attachment between the individual and } \\
\text { the ski resort (Lacoeuilhe, 1991: brand attachment scale) }\end{array}$ \\
\hline
\end{tabular}


TABLE 3

Confirmatory Factor Analysis: Standardized Coefficients, Reliability and Average Variance Extracted $(N=$ 753)

\begin{tabular}{|c|c|c|c|c|}
\hline & & $\begin{array}{c}\text { Standardized } \\
\text { coefficients }\end{array}$ & $\begin{array}{l}\text { Reliability } \\
(*)(C F A) 1\end{array}$ & $\begin{array}{l}\text { Average } \\
\text { variance } \\
\text { extracted } \\
(A V E) 2\end{array}$ \\
\hline \multirow[t]{4}{*}{ Self-confidence } & $\begin{array}{l}\text { I have never regretted the holiday choices that I } \\
\text { have made }\end{array}$ & 0.69 & 0.80 & 0.51 \\
\hline & $\begin{array}{l}\text { I believe that I am capable of properly } \\
\text { organizing my different holiday getaways }\end{array}$ & 0.74 & & \\
\hline & $\begin{array}{l}\text { To date, I think that I have chosen my holiday } \\
\text { getaways well }\end{array}$ & 0.66 & & \\
\hline & I am good at planning holiday getaways & 0.75 & & \\
\hline \multirow{5}{*}{$\begin{array}{l}\text { Ego- } \\
\text { reinforcement }\end{array}$} & It is a resort to which you are deeply attached & 0.89 & 0.91 & 0.66 \\
\hline & $\begin{array}{l}\text { It is a resort which, to a certain extent, is part of } \\
\text { you and your personal history }\end{array}$ & 0.86 & & \\
\hline & $\begin{array}{l}\text { Grand Bornand ski resort has great personal } \\
\text { significance for me }\end{array}$ & 0.86 & & \\
\hline & It is a resort to which you feel a close attachment & 0.75 & & \\
\hline & $\begin{array}{l}\text { I feel personally concerned about the future of } \\
\text { Grand Bornand ski resort }\end{array}$ & 0.68 & & \\
\hline \multirow[t]{4}{*}{$\begin{array}{l}\text { Helping the } \\
\text { company }\end{array}$} & $\begin{array}{l}\text { I sometimes post positive comments to support } \\
\text { regional economic development }\end{array}$ & 0.90 & 0.81 & 0.54 \\
\hline & $\begin{array}{l}\text { I post positive comments to help boost local } \\
\text { tourism }\end{array}$ & 0.91 & & \\
\hline & $\begin{array}{l}\text { I attempt to set the record straight about Grand } \\
\text { Bornand ski resort by posting comments on } \\
\text { the Web }\end{array}$ & 0.52 & & \\
\hline & $\begin{array}{l}\text { I defend Grand Bornand ski resort on the } \\
\text { Internet }\end{array}$ & 0.49 & & \\
\hline \multirow[t]{4}{*}{ Vengeance } & $\begin{array}{l}\text { For me personally, it is important to be able to } \\
\text { publicly denounce hotels and restaurants with } \\
\text { bad business practices }\end{array}$ & 0.73 & 0.84 & 0.58 \\
\hline & $\begin{array}{l}\text { It is good to be able to vent on the Internet when } \\
\text { one has had an unpleasant experience }\end{array}$ & 0.69 & & \\
\hline & $\begin{array}{l}\text { Thanks to the Internet, consumers can publicly } \\
\text { denounce bad business practices by various } \\
\text { hotels and restaurants }\end{array}$ & 0.84 & & \\
\hline & $\begin{array}{l}\text { With the Internet, tourists are freer and can more } \\
\text { readily say what they think }\end{array}$ & 0.76 & & \\
\hline \multirow[t]{3}{*}{$\begin{array}{l}\text { Other customer } \\
\text { honesty }\end{array}$} & $\begin{array}{l}\text { Tourist comments on online forums are } \\
\text { trustworthy }\end{array}$ & 0.74 & 0.80 & 0.50 \\
\hline & $\begin{array}{l}\text { Browsers who post comments on the Internet are } \\
\text { generally sincere }\end{array}$ & 0.72 & & \\
\hline & $\begin{array}{l}\text { I get the impression that consumers who post } \\
\text { comments on the Internet use the same } \\
\text { evaluation criteria as I do }\end{array}$ & 0.66 & & \\
\hline $\begin{array}{l}\text { Other company } \\
\text { honesty }\end{array}$ & $\begin{array}{l}\text { Certain tourism sector professionals post their } \\
\text { own positive comments on the Internet }\end{array}$ & 0.67 & 0.82 & 0.70 \\
\hline
\end{tabular}




\begin{tabular}{|c|c|c|c|c|}
\hline & & $\begin{array}{l}\text { Standardized } \\
\text { coefficients }\end{array}$ & $\begin{array}{l}\text { Reliability } \\
(*)(C F A) 1\end{array}$ & $\begin{array}{l}\text { Average } \\
\text { variance } \\
\text { extracted } \\
(A V E) 2\end{array}$ \\
\hline & $\begin{array}{l}\text { Numerous Web-based comments are laughed off } \\
\text { by some hoteliers and restaurateurs }\end{array}$ & 0.97 & & \\
\hline \multirow[t]{8}{*}{$\begin{array}{l}\text { Collective } \\
\text { consciousness }\end{array}$} & $\begin{array}{l}\text { The possibility of expressing oneself on the } \\
\text { Internet gives consumers. myself included, } \\
\text { power that we did not have before }\end{array}$ & 0.74 & 0.87 & 0.50 \\
\hline & $\begin{array}{l}\text { Individuals in search of advice will find } \\
\text { interesting information on these opinion } \\
\text { platforms }\end{array}$ & 0.69 & & \\
\hline & $\begin{array}{l}\text { When feedback is positive, others are inspired to } \\
\text { discover the tourist destination }\end{array}$ & 0.71 & & \\
\hline & $\begin{array}{l}\text { Thanks to the Internet, tourists exert ever } \\
\text { increasing power over companies }\end{array}$ & 0.64 & & \\
\hline & $\begin{array}{l}\text { Thanks to the Internet, consumers can more } \\
\text { readily 'punish bad' and 'reward good' } \\
\text { service providers such as hotels, restaurants, } \\
\text { etc. }\end{array}$ & 0.65 & & \\
\hline & $\begin{array}{l}\text { These comments spur professionals to } \\
\text { progressively enhance their services }\end{array}$ & 0.75 & & \\
\hline & $\begin{array}{l}\text { Thanks to the Internet, consumers are better able } \\
\text { to reward professionals who do a good job }\end{array}$ & 0.74 & & \\
\hline & $\begin{array}{l}\text { Comments posted on the Internet are generally } \\
\text { reliable }\end{array}$ & 0.71 & & \\
\hline \multirow{2}{*}{$\begin{array}{l}\text { Altruism } \\
\text { towards other } \\
\text { customers }\end{array}$} & $\begin{array}{l}\text { These comments can help tourists make their } \\
\text { choices }\end{array}$ & 0.87 & 0.88 & 0.78 \\
\hline & These comments are useful to other tourists & 0.89 & & \\
\hline
\end{tabular}

${ }^{1}$ Werts, Linn, and Jöreskog (1974): $\rho=\left(\sum \lambda_{y i}\right)^{2} /\left[\left(\sum \lambda_{y i}\right)^{2}+\sum \operatorname{Var}(\varepsilon i)\right]$ with $\operatorname{Var}(\varepsilon i)=1-\lambda_{y i}^{2}$.

${ }^{2}$ Fornell and Larcker (1981): $\operatorname{AVE}=\sum \lambda_{y i}^{2} /\left[\sum \lambda_{y i}^{2}+\sum \operatorname{Var}(\varepsilon i)\right]$.

TABLE 4

Correlation Matrix $(N=753)$

\begin{tabular}{|c|c|c|c|c|c|c|c|c|}
\hline & 1 & 2 & 3 & 4 & 5 & 6 & 7 & 8 \\
\hline 1. Self-confidence & $0.71 * *$ & & & & & & & \\
\hline 2. Ego-reinforcement & 0.12 & 0.8 & & & & & & \\
\hline 3. Helping the company & 0.04 & 0.16 & 0.73 & & & & & \\
\hline 4. Vengeance & 0.22 & 0.06 & 0.30 & 0.76 & & & & \\
\hline 5. Other client honesty & 0.15 & -0.02 & 0.32 & 0.57 & 0.71 & & & \\
\hline 6. Other company honesty & 0.06 & 0.00 & -0.07 & 0.07 & -0.23 & 0.84 & & \\
\hline 7. Collective consciousness & 0.24 & 0.07 & 0.33 & 0.77 & 0.59 & -0.09 & 0.71 & \\
\hline 8. Altruism towards other customers & 0.27 & 0.02 & 0.18 & 0.74 & 0.57 & -0.04 & 0.74 & 0.88 \\
\hline
\end{tabular}

** Root AVE (average variance extracted). 
"5" = "very often"). To measure the eight independent variables, we employed measurement scales developed in topical literature (Please see Table 2).

These scales were adapted to the e-tourism context and translated into French. We used the same format for all items (Likert scales where "1" = "strongly disagree" and " 5 " = "strongly agree"). We first performed an Exploratory Factor Analysis (oblimin). As expected, this led to the extraction of nine factors. The measurement scales showed the psychometric qualities to be adequate, even though the items were mixed in the questionnaire so as not to increase artificially the validity of the measures. Using the structural equations method, we then performed a Confirmatory Factor Analysis (as presented in Table 3 in the appendix) with these 8 constructs (latent variables) and 32 items (manifest variables). All constructs exhibited a satisfactory degree of convergent validity: standardized factor loadings were all significant and varied between 0.60 and 0.94 ; average variances extracted ranged from 0.50 to 0.78 , indicating that the variance of each construct was better explained by its measures than by error (Fornell and Larcker 1981). Reliability coefficients (Rho) were also satisfactory (between 0.80 and 0.91$)$, as presented in the appendix in Table 4.

\section{FINDINGS}

Our research confirms and complements previous studies (Hennig-Thurau et al. 2004), which underline collective capacities but fail to consider personal and relational capacities. Some links from the qualitative study were validated in the quantitative study, and some changed. Ego reinforcement, helping the company and the other customers' honesty were validated, whereas other variables were found not to be significant. We also observed that customers did not seek approval from others through Web 2.0. In this study, we simultaneously considered opinion seeking and opinion giving, and demonstrate that they are not totally independent of one another.

For the purpose of this quantitative study, we apply structural equation modeling (Amos software) to test the hypotheses presented in Figure $2(\mathrm{RMSEA}=0.06)$. The results appear in Table 5. The study findings generated from our psychological empowerment conceptual model are sorted based on the three targets of the power exercise, namely self, other, and others.

TABLE 5

Summary of the Results

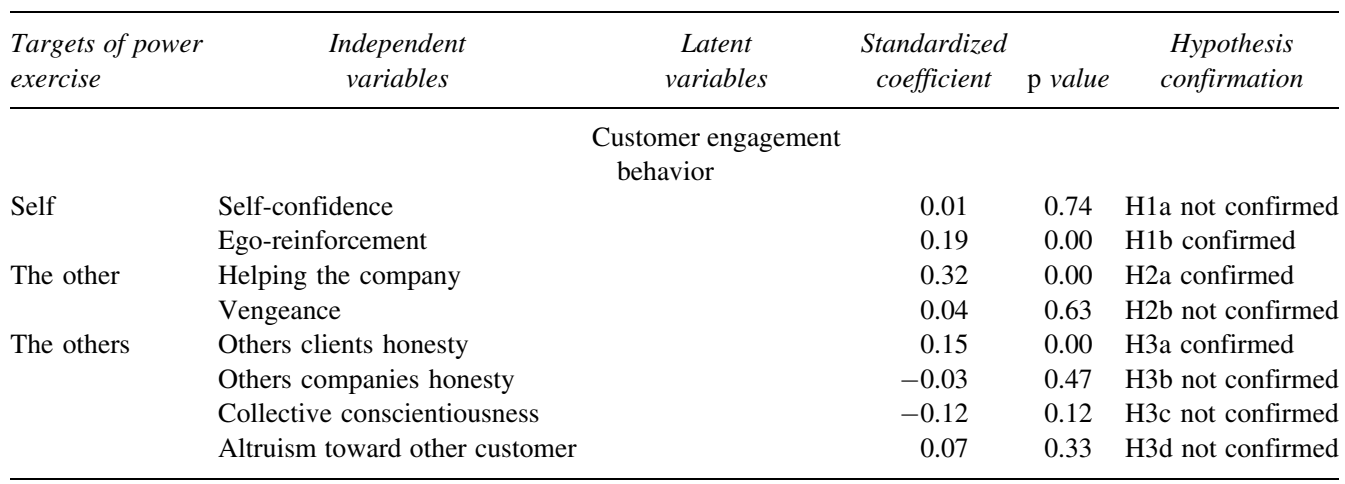




\section{Findings Respecting the "Self" Target}

Contrary to expectations, the fact that tourists demonstrated confidence in their expertise and competence did not impact their online engagement respecting the ski resort. Moreover, we note that, in the tourism industry, customer ego-reinforcement readily influences engagement in opinion platforms. Customers strive to establish a link to the ski resort, a link integrated into their own history and identity. The more attached customers are to the service brand, the more likely they are to be active on opinion platforms. Brand-attached tourists tend to engage and contribute to the development of the resort and the surrounding region. There is true resonance with the future of the resort, a finding which is critical given that the company is seeking to develop its e-reputation.

\section{Findings Respecting the "Other" Target}

In the qualitative study, we found Internet users to be skeptical of online marketer practices. They readily questioned brand confidence and suspected the company of manipulation. However, in contrast to expectations, this finding did not impact customer engagement behavior in the quantitative study.

In the qualitative study, some customers demonstrated altruism towards the company, while others exerted their power through vengeance. The quantitative study confirms customer willingness to help the resort develop, improve products and services, and promote it. More generally, customer willingness to help can be directed at one or more companies or regions and extend to thrusts, such as corporate and regional economic development. Contrary to what the company might think, customers want to help the ski resort and do not seek to use vengeance.

\section{Findings Respecting the "Others" Target}

In the qualitative study, all customers have demonstrated altruism towards other customers, evidenced their desire to restore balance in the relationship between them as a group and the company, and perceived online commentaries as sincere. Seemingly, sincere online commentaries are more likely to prompt engagement through reciprocity. The quantitative study confirms the importance of perceived sincerity, the latter being essential to customer engagement, respecting the resort. Indeed, when online platform commentaries appear to be sincere, customers tended to be less skeptical and engage.

Our studies, therefore, highlight the interaction of the different targets in the exercise of power. Customers willingly seek to achieve a rebalancing of power through collective capacities. However, they remain highly skeptical about the perceived sincerity of commentaries. In fact, they engage primarily for the "Other" or company to which they are attached. Customers are found to contribute to e-reputations mainly to help a company, which is crucial for an organization seeking to secure a sound e-reputation. 


\section{DISCUSSION}

\section{Linking Customer Psychological Empowerment and Company Empowerment Strategies}

This article focuses on customer psychological empowerment and the relationship of the latter to customer online engagement. The conceptual framework developed highlights customer capacity to impact a company's e-reputation. The following three specific targets of empowerment were identified: the "Self," the "Other," and the "Others" target. Findings show that psychological empowerment positively impacts customer online engagement.

How can these results help companies tackle two conflicting objectives relating to e-reputations, namely enhancing customer online engagement while controlling and influencing what is published online? How can brands incorporate psychological empowerment into strategies based on structural empowerment? The key managerial contribution of this article is the idea that companies experience difficulty in attracting audiences to online platforms should empower customers and other stakeholders. While approximately $70 \%$ of customers are content to spectate, 15 to $20 \%$ remain totally inactive (Fleming 2012). The object is to transform these spectators or "lurkers" into creators and contributors (Poetz and Schreier 2012), and to have them assume an active role in shaping e-reputations. To get them to do so, companies must stand up for free speech. Indeed, empowerment entails lending influence and authority not only to customers, but also to other stakeholders as well. Our results suggest that to engage stakeholders, managers must shy away from attempting to control what is said online, a move certain to bolster company e-reputations. In the same manner as customer free speech contributes to company e-reputations, marketing activities provide for an enhanced understanding of issues relating to organizational studies. Our research findings make a case for more horizontal communications and more equal relationships between companies and their stakeholders.

More specifically, as results indicate, customers require accountability, self-directed decision-making, and skills development to spur ego-reinforcement (H1b). Companies must therefore become more accountable by lending more power to stakeholders and helping reinforce stakeholder egos. Companies could encourage stakeholders to engage online by rewarding them personally and adapting as required by drawing on the means set out in the structural empowerment framework for influencing employees. Results show that psychological empowerment through ego-reinforcement positively impacts customer engagement. Customers reinforce the self through support for a destination that they like or to which they relate. The more self-confident they are, the more likely they are to engage. Companies can trust and encourage stakeholders to engage online to promote the resort. The "Self" target relates to the "power to." Translated into terms of structural empowerment, this means that companies could use the following elements to encourage stakeholders to engage online:

\section{Accountability}

Companies should make known to their most engaged customers that they figure among the leading contributors. As accountability infers customer responsibility towards a commercial 
enterprise, companies should openly recognize and value customer accountability given the promise of e-reputation gains to be achieved through customer reviews.

\section{Self-Directed Decision-Making and Participation in Decision-Making}

Companies need to thank contributors and point out that their contributions are essential from the dual standpoint of decision-making and business development.

\section{Skills Development}

Companies should provide premium offerings for their best contributors with a view to promoting skills development and using the latter for information and education purposes.

Secondly, companies should not shy from delegating power to customers given online engagement by the latter to help (H2a). To enhance their e-reputations, companies should aim to build relationships based on mutual trust and let an "invisible hand" regulate consumer opinions. The findings show that stakeholders engage online to help companies and that most do not view their participation in opinion platforms as acts of destruction. Since the "Other" target relates to "power on," companies can enhance customer engagement by granting a degree of "power on."

Companies must, therefore, trust customers when they engage online and draw on the following elements relating to structural empowerment.

\section{Delegation of Authority}

Knowing that customers engage primarily to help companies, the latter must demonstrate trust in their customers and exhibit transparency respecting customer review management. More specifically, through the delegation of authority, companies must underscore clearly the extent to which customer comments contribute to company development, thereby showcasing the essential role played by customer engagement. Companies must delegate a measure of authority to engage customers. Hence the role of the community manager is critical. He or she must respond to negative comments and demonstrate how they have helped a company to improve and how important they are to effective business management.

\section{Coaching for Innovative Performance}

Stakeholders engage to help companies. Companies must therefore encourage them to become engaged through co-innovation and by offering online contributors a chance to get involved through crowdsourcing in the development of new products and services together with company authorities.

As findings herein illustrate, customers tend to engage online when they perceive other customers as demonstrating honesty (H3a). Indeed, the guaranteed fairness and authenticity of comments posted fosters customer online engagement. Empowerment occurs only when customers sense that they can trust what other customers have to say. Community managers must therefore monitor what is written online without manipulating reviews and screening negative opinions. The role of the community manager is to underscore control mechanisms 
implemented to ensure the conveyance of trustworthy comments. The "Others" target relates to the "power with" dimension of empowerment. In terms of structural empowerment, companies can boost customer empowerment by granting a measure of "power with" through the following elements:

\section{Information Sharing}

Companies must reassure customers by demonstrating the veracity of available comments and providing tangible evidence of truthfulness. By encouraging contributors to submit photos and proofs of purchase (in exchange for rewards), they should be able to readily substantiate contributor honesty.

\section{Feedback}

All feedback and sharing of stakeholder experiences should be checked for veracity and objectivity. The role of companies in this regard is to guarantee the truthfulness of online comments and to advise customers accordingly. Shared information becomes more effective as a result and more likely to generate additional customer feedback capable of enhancing company e-reputations.

The foregoing points mentioned highlight the link between psychological and structural empowerment, and the ultimate impact on e-reputation. Structural empowerment should aim to enrich customer psychological empowerment with skills and abilities designed to satisfy customer needs and requests. E-reputations can subsequently be built and linked to organizational success. To diminish customer skepticism, managers must make a point of stressing the sincerity of online reviews and avoiding opportunistic online practices. They must trust their customers, or otherwise they will be unable to transform customers into e-reputation contributors who generate content and promote the company.

The example of the case of the ski resort provides proof positive that residents themselves assume an active role in online platforms. One could, therefore, surmise that employees and professionals from all sectors are particularly active online, even more than customers whose active online presence is more occasional. These other stakeholders concern themselves with issues specific to the ski resort and local development. They act as "partial employees" (Mills and Morris 1986) who visit regularly and play a particularly special role in promoting and conveying the resort's e-reputation. Their involvement indeed begs questions about the disappearance of organizational boundaries (Santos and Eisenhardt 2005). That said, these "partial employee" stakeholders can impact companies both positively and negatively. They are not bound by company controls, but do exert significant impact within the organizational hierarchy. Hence they have the power to decimate the online reputation of a company's products, brands, and staff, which, in turn, can impact other business audiences, including "real" employees. The latter view their company from the outside based on what customers say, albeit comments are sometimes inconsistent with official internal communications. This can have an impact in terms of service quality within the company, since it will be a regulation, but also a destabilization of employees if comments are negative.

Web 2.0, therefore, blurs company boundaries, rendering them more porous in the exercise of regulatory power. 
Psychological and structural empowerment form part of a more global analysis of power distribution within a company or organization. Employee empowerment positively impacts customer relationships and company performance as empirically substantiated in the study by Gremler, Gwinner, and Brown (2001). This study nonetheless raises a number of questions: How is customer integration into company functioning managed? How do employee empowerment and customer psychological empowerment relate to one another? Do the two conflict in any way? Dong et al. (2012) explain that customer psychological empowerment and employee empowerment are interrelated. Their findings reveal the positive impact of customer empowerment behavior on employee service creativity. Companies would therefore be well advised to empower and engage customers properly with view to bolstering employee service creativity.

\section{Limitations and Areas of Research}

The purpose of this study was to examine the impact of customer psychological empowerment on customer engagement and that companies might incorporate the concept into their structural empowerment strategies. While abundant and adequate precautions have been taken, our study is not without a number of limitations. Firstly, it would be interesting to extend our research to other product categories, other population groups, and other cultures. It would also be interesting to analyze the impact of engagement on collective power. Although we have discussed the influence of perceived customer psychological empowerment on customer engagement, the process is circular, and one is given to wonder whether enhanced customer engagement engenders added collective power. Lastly, it would be useful to analyze the impact of psychological reactance on collective power and to examine the moderating effect, if any, on collective power, of negative reactions by individuals, to attempts to control their online freedom.

\section{REFERENCES}

Anderson, J. C., and J. A. Narus. 1990. "A Model of Distributor Firm and Manufacturer Firm Working Partnerships." Journal of Marketing 54(1):42-58. doi:10.2307/1252172

Bernoff, J., and T. Schadler. 2010. Empowered: Unleash Your Employees, Energize Your Customers, and Transform Your Business Hardcover. Boston, MA: Harvard Business Review Press.

Brodie, R. J., A. Ilic, L. D. B. Juric, and L. Hollebeek. 2011. "Consumer Engagement in a Virtual Brand Community: An Exploratory Analysis.” Journal of Business Research 66(1):314-329. doi:10.1016/j.jbusres.2011.07.029

Campbell, M. C. 1999. "Perceptions of Price Unfairness: Antecedents and Consequences." Journal of Marketing Research 36(2):187-199. doi:10.2307/3152092

Castellano, S., and V. Dutot. 2013. "Une Analyse de l'E-reputation par Analogie ou Contraste avec la Réputation: une Approche par les Medias Sociaux.” Revue Française du Marketing 243(3):35-51.

Chevalier, J. A., and D. Mayzlin. 2006. "The Effect of Word of Mouth on Sales: Online Book Reviews.” Journal of Marketing Research 43(3):345-354. doi:10.1509/jmkr.43.3.345

Cho, T., and S. R. Faerman. 2010. "An Integrative Approach to Empowerment: Construct Definition, Measurement, and Validation." Public Management Review 12(1):33-51. doi:10.1080/14719030902798610

Chun, R., and G. Davies. 2001. "E-reputation: the Role of Mission and Vision Statements in Positioning Strategy." Journal of Brand Management 8(4):315-333. doi:10.1057/palgrave.bm.2540031

Churchill, G. A. 1979. "A Paradigm for Developing Better Measures of Marketing Constructs.” Journal of Marketing Research 16(4):64-73. doi:10.2307/3150876 
Conger, J. A., and R. N. Kanungo. 1988. "The Empowerment Process: Integrating Theory and Practice.” Academy of Management Review 13(3):471-482. doi:10.5465/amr.1988.4306983

Denegri-Knott, J., D. Zwick, and J. E. Schroeder. 2006. "Mapping Consumer Power: An Integrative Framework for Marketing and Consumer Research.” European Journal of Marketing 40(9/10):950-971. doi:10.1108/ 03090560610680952

Dong, Y., H. Liao, A. Chuang, J. Zhou, and E. M. Campbell-Bush. 2012. “An Invisible Hand in Employee Service Creativity: Customer Empowering Behaviors." Proceedings of the 72nd Annual Meeting of the Academy of Management, San Antonio, TX, edited by L. A. Toombs, 1543-8643.

Engel, J. F., R. D. Blackwell, and P. W. Miniard. 1993. Consumer Behavior, 8th ed. Fort Worth, TX: The Dryden Press.

Escalas, J. E., and J. R. Bettman. 2003. "You Are What They Eat: The Influence of Reference Groups on Consumers' Connections to Brands.” Journal of Consumer Psychology 13(3):339-348. doi:10.1207/s15327663jcp1303_14

Fleming, G. 2012. "Global Social Technographics Update 2011: US and EU Mature, Emerging Markets Show Lots of Activity.” Accessed January 12, 2014. http://blogs.forrester.com/gina_sverdlov/12-01-04-global_social_ technographics_update_2011_us_and_eu_mature_emerging_markets_show_lots_of_activity

Fornell, C., and D. F. Larcker. 1981. "Structural Equation Models with Unobservable Variables and Measurement Error: Algebra and Statistics." Journal of Marketing Research 18(3):382-388. doi:10.2307/3150980

Fournier, S. 1998. "Consumers and their Brands, Developing Relationships Theory in Consumer Research." Journal of Consumer Research 24(4):343-353. doi:10.1086/209515

French, J. R. P., and B. Raven. 1959. The Bases of Social Power. New York, NY: Harper \& Row.

Frisou, J. 2000. "Confiance Interpersonnelle et Engagement: Une Réorientation Behavioriste." Recherche et Applications en Marketing 15(1):63-80. doi:10.1177/076737010001500104

Fuchs, C., and M. Schreier. 2011. "Customer Empowerment in New Product Development." Journal of Product Innovation Management 28(1):17-32. doi:10.1111/j.1540-5885.2010.00778.x

Füller, J. 2006. "Why Consumers Engage in Virtual New Product Developments Initiated by Producers." In Advances in Consumer Research, edited by C. Pechmann and L. Price, 639-646. Duluth, MN: Advances for Consumer Research.

Füller, J., H. Mühlbacher, K. Matzler, and G. Jawecki. 2010. "Consumer Empowerment through Internet-Based Co-creation.” Journal of Management Information Systems 26(3):71-102. doi:10.2753/mis0742-1222260303

Godes, D., and D. Mayzlin. 2004. "Using Online Conversations to Study Word-of-Mouth Communication.” Marketing Science 23(4):545-560. doi:10.1287/mksc.1040.0071

Gremler, D., K. P. Gwinner, and S. W. Brown. 2001. "Generating Positive Word-of-Mouth Communication through Customer-Employee Relationships." International Journal of Service Industry Management 12(1):44-59. doi:10.1108/09564230110382763

Harrison, T., K. Waite, and G. L. Hunter. 2006. “The Internet, Information and Empowerment.” European Journal of Marketing 40(9/10):972-993. doi:10.1108/03090560610680961

Hennig-Thurau, T., K. P. Gwinner, G. Walsh, and D. D. Gremle. 2004. "Electronic Word-of-Mouth via Consumeropinion Platforms: What Motivates Consumers to Articulate Themselves on the Internet?" Journal of Interactive Marketing 18(1): 38-52.

Hennig-Thurau, T., V. Henning, and H. Sattler. 2007. "Consumer File Sharing of Motion Pictures." Journal of Marketing 71(4):1-18. doi:10.1509/jmkg.71.4.1

Jahn, B., and W. Kunz. 2012. "How to Transform Consumers into Fans of Your Brand." Journal of Service Management 23(3):344-361. doi:10.1108/09564231211248444

Johnson, J. W., and A. Rapp. 2010. "A More Comprehensive Understanding and Measure of Customer Helping Behavior.” Journal of Business Research 63(8):787-792. doi:10.1016/j.jbusres.2008.03.006

Konczak, L. J., D. J. Stelly, and M. L. Trusty. 2000. "Defining and Measuring Empowering Leader Behaviors: Development of an Upward Feedback Instrument." Educational and Psychological Measurement 60(2):301-313. doi:10.1177/00131640021970420

Lacoeuilhe, J. 1999. "Proposition d'une Échelle de Mesure de l'Attachement à la Marque." Paper presented at the Association Française du Marketing 15th conference, Strasbourg, France, May, 1067-1085.

Lawer, C., and S. Knox. 2008. "Reverse-Market Orientation and Corporate Brand Development." International Studies of Management \& Organization 37(4):64-83. doi:10.2753/imo0020-8825370403

Liu, Y. 2006. "Word of Mouth for Movies: Its Dynamics and Impact on Box Office Revenue." Journal of Marketing 70(3):74-89. doi:10.1509/jmkg.70.3.74 
Matthews, R. A., W. M. Diaz, and S. G. Cole. 2002. "The Organizational Empowerment Scale.” Personnel Review 32(3):297-318. doi:10.1108/00483480310467624

Mills, P. K., and J. H. Morris. 1986. "Clients as 'Partial Employees' of Service Organizations: Role Development in Client Participation.” Academy of Management Review 11(4):726-735. doi:10.5465/amr.1986.4283916

Minazzi, R. 2015. Social Media Marketing in Tourism and Hospitality. Cham, Switzerland: Springer International Publishing.

Moe, W. W., and M. Trusov. 2011. "The Value of Social Dynamics in Online Product Ratings Forums.” Journal of Marketing Research 48(3):444-456. doi:10.1509/jmkr.48.3.444

Murdough, C. 2009. "Social Media Measurement: It's Not Impossible.” Journal of Interactive Advertising 10(1):94-99. doi:10.1080/15252019.2009.10722165

Netzer, O., R. Feldman, J. Goldenberg, and M. Fresco. 2012. "Mine Your Own Business: Market Structure Surveillance through Text Mining." Marketing Science 31(3): 521-543. doi:10.1287/mksc.1120.0713

Pan, B., and D. R. Fesenmaier. 2006. "Online Information Search and Trip Planning Process." Annals of Tourism Research 33(3):809-832.

Paquerot, M., A. Queffelec, I. Sueur, and G. Biot-Paquerot. 2011. "L'E-réputation ou le Renforcement de la Gouvernance par le Marché de l'Hôtellerie?" Revue Management et Avenir 45(5):294-331. doi:10.3917/ mav.045.0280

Park, C. W., D. J. MacInnis, J. Priester, A. B. Eisingerich, and D. Iacobucci. 2010. "Brand Attachment and Brand Attitude Strength: Conceptual and Empirical Differentiation of Two Critical Brand Equity Drivers." Journal of Marketing 74(4):1-17. doi:10.1509/jmkg.74.6.1

Poetz, M. K., and M. Schreier. 2012. "The Value of Crowdsourcing: Can Users Really Compete with Professionals in Generating New Product Ideas?” Journal of Product Innovation Management 29(2):245-256. doi:10.1111/j.15405885.2011.00893.x

Prabhu, J., and D. W. Stewart. 2001. "Signaling Strategies in Competitive Interaction: Building Reputations and Hiding the Truth." Journal of Marketing Research 38(1):62-72. doi:10.1509/jmkr.38.1.62.18826

Robert, A. D., and A. Bouillaguet. 1997. L'Analyse de Contenu. Paris, France: Presses Universitaires de France.

Rowlands, J. 1995. "Empowerment Examined." Development in Practice 5(2):101-107. doi:10.1080/0961452951 000157074

Santos, F. M., and K. M. Eisenhardt. 2005. "Organizational Boundaries and Theories of Organization." Organization Science 16(5):491-508. doi:10.1287/orsc.1050.0152

Savoie-Zajc, L. 2000. "L'Analyse de Données Qualitatives: Pratiques Traditionnelle et Assistée par le Logiciel NUD*IST.” Recherches qualitatives 21(1):99-123.

Sher, P., and S. Lee. 2009. "Consumer Skepticism and Online Reviews: An Elaboration Likelihood Model Perspective." Social Behavior and Personality 37(1):137-143. doi:10.2224/sbp.2009.37.1.137

Spreitzer, G. M. 1995. "Psychological Empowerment in the Workplace: Dimensions, Measurement, and Validation." Academy of Management Journal 38(5):1442-1465. doi:10.2307/256865

Spreitzer, G. M. 1997. "Toward a Common Ground in Defining Empowerment." Research in Organizational Change and Development 10(1):31-62.

Sundaram, D. S., K. Mitra, and C. Webster. 1998. "Word-of-Mouth Communications: A Motivational Analysis." Advances in Consumer Research 25(1):527-531.

Tesch, R. 1990. Qualitative Research: Analysis Types and Software Tools, New York. NY: The Falmer Press.

Thomas, K. W., and B. A. Velthouse. 1990. "Cognitive Elements of Empowerment: An Interpretive Model of Intrinsic Task Motivation.” Academy of Management Journal 15(4):666-681. doi:10.5465/amr.1990.4310926

Thompson, S. A., and R. K. Sinha. 2008. "Brand Communities and New Product Adoption: The Influence and Limits of Oppositional Loyalty." Journal of Marketing 72(6):65-80. doi:10.1509/jmkg.72.6.65

Tirunillai, S., and G. J. Tellis. 2012. "Does Chatter Really Matter? Dynamics of User-Generated Content and Stock Performance." Marketing Science 31(2):198-215. doi:10.1287/mksc.1110.0682

Trusov, M., R. E. Bucklin, and K. Pauwels. 2009. "Effects of Word-of-Mouth Versus Traditional Marketing: Findings from an Internet Social Networking Site." Journal of Marketing 73(5):90-102. doi:10.1509/jmkg. 73.5.90

Tuuli, M. M., and S. Rowlinson. 2007. "Empowering Project Teams: Toward an Integrative Conceptualization of Empowerment." Proceedings of the 4th International Conference on Construction in the 21st Century, Gold Coast, Australia, edited by S. M. Ahmed, S. Azhar and S. Mohamed, 240-247. 
Van Doorn J., K. N. Lemon, V. Mittal, S. Naß, D. Pick, P. Pirner, and P. Verhoef. 2010. "Customer Engagement Behavior: Theoretical Foundations and Research Directions." Journal of Service Research 13(3):253-266. doi:10.1177/1094670510375599

Wathieu, L., L. Brenner, Z. Carmon, A. Chattopadhay, K. Wetenbroch, A. Drolet, J. Gourville, A. Muthukrishnan, N. Novemsky, R. K. Ratner, and G. Wu. 2002. "Consumer Control and Empowerment: A Primer.” Marketing Letters 13(3):297-305.

Weber, M. 1947. The Theory of Social and Economic Organization. Oxford, UK: Oxford University Press.

Werts, C. E., R. L. Linn, and K. G. Jöreskog. 1974. "Intraclass Reliability Estimates: Testing Structural Assumptions." Educational and Psychological Measurement 34(1):25-33.

Wright, L. T., A. Newman, and C. Dennis. 2006. "Enhancing Customer Empowerment." European Journal of Marketing 40(9/10):925-935.

Xiang, Z., and D. R. Fesenmaier. 2006. "Understanding Interface Metaphors on Travel Related Websites." In Travel Destination Recommendation Systems: Behavioral Foundations and Applications, edited by D. R. Fesenmaier, H. Werthner, and K. Wöber, 180-189. London, UK: CABI Publishing.

Xiang, Z., and U. Gretzel. 2010. "Role of Social Media in Online Travel Information." Tourism Management 31(2):179-188. doi:10.1016/j.tourman.2009.02.016

Yoo, K. H., and U. Gretzel. 2012. "Use and Creation of Social Media by Travelers.” In Social Media in Travel, Tourism and Hospitality: Theory, Practice and Cases, edited by M. Sigala, E. Christou, and U. Gretzel, 189-207. Surrey, UK: Ashgate. 